\title{
Annette Volfing, Oriel College, Oxford \\ Honour and Fortune Outside the Box: Frauenlob's Response to Walther von der Vogelweide (VII,15 and VII,16)
}

The aim of this article is to offer a new reading of two 'Sprüche' by Frauenlob (VII,15 and VII,16) that function as a response to the first 'Spruch' in the 'Reichston' of Walther von der Vogelweide (I.2.I). ${ }^{1}$ The first section will provide an exposition of the contents of these 'Sprüche' and of the intertextual connections between Walther and Frauenlob. The discussion in the second section will consider Frauenlob's wider engagement with the concept of Fortune, whilst the third section will focus specifically on the interaction between the personifications vrou Ere and Gelücke in VII,16. This third section will also address the themes of linguistic ambiguity and equivocation that run through both 'Sprüche', culminating in Gelücke's provocative assertion that die wort sint nicht gespalden (VII,16,19). Finally, the fourth section will sum up the ways in which Frauenlob's approach differs from that of Walther.

\footnotetext{
${ }^{1}$ Frauenlob (Heinrich von Meissen): Leichs, Sangsprüche, Lieder. Göttingen Abhandlungen der Akademie der Wissenschaften in Göttingen, Philologisch-historische Klasse, Dritte Folge 119-120, ed. by Karl Stackmann and Karl Bertau, 2 vols. (Göttingen: Vandenhoeck \& Ruprecht, 1981); Walther von der Vogelweide: Leich, Lieder, Sangsprüche, ed. by Christoph Cormeau, with contributions by Thomas Bein and Horst Brunner, based on the edition by Karl Lachmann (Berlin: De Gruyter, 1996).
} 
The three linked Sprüche in the 'Reichston', in which Walther's persona reflects on the moral and political turbulence marking the end of the twelfth century, constitute one of the most famous literary compositions of the medieval German period. ${ }^{2}$ Of these, the first 'Spruch' is perhaps the most iconic, given that it opens with a vivid representation of the persona in a thoughtful, and possibly melancholic, pose:

Ich saz ûf eime steine und dahte bein mit beine. dar ûf sazte ich den ellenbogen, ich hete in mîne hant gesmogen mîn kinne und ein mîn wange.

The topic preoccupying the thinker is nothing less than wes man zer welte solte leben (7). This broad existential question is immediately reformulated by reference to the apparently insoluble problem of how one might enjoy both wealth and honour without forfeiting God's favour. These three desiderata are configured as tangible objects which the persona would like to fit into a single container:

dekeinen rât konde ich gegeben, wie man driu dinc erwurbe, der deheinez niht verdurbe. diu zwei sint êre und varnde guot, daz dicke ein ander schaden tuot.

\footnotetext{
${ }^{2}$ For the extensive secondary literature on the 'Reichston', see Jens Burkert, Walthers von der Vogelweide „Reichston“: Eine kritische Aufarbeitung der altgermanistichen und historischen Forschungsgeschichte. Walther-Studien 8 (Frankfurt am Main: Peter Lang, 2015).
} 
daz dritte ist gotes hulde, der zweier übergulde. die wolte ich gerne in einen schrîn, jâ leider des enmac niht sîn, daz guot und weltliche êre und gotes hulde mêre zesame in ein herze komen. (I.2.I,7-19)

In order to explain why this cannot be achieved, the persona brings a series of further abstractions into play:

stîg und wege sint in benomen:

untriuwe ist in der sâze, gewalt vert ûf der strâze, fride und reht sint sêre wunt. diu driu enhabent geleites niht, diu zwei enwerden ê gesunt. (I.2.I,20-24)

These new abstractions are not just tangible objects, but come close to functioning as animate personifications: Peace and Justice possess wounded bodies; Treachery lies in wait and Violence controls the roads. Even the configuration of the original three desiderata has shifted slightly. They are no longer just inanimate objects requiring storage, but seem to have acquired a dynamic telos or spatial goal - even if the prevailing unsafe road conditions mean that they cannot achieve it. Of course, by linking the problem to external factors, the persona does in fact offer a potential solution. It may not be particularly clear how these factors might be changed (i.e. how one might unseat Treachery, tame Violence, and heal Peace and Justice), but, by even mentioning them, he creates the impression that the three desidarata are not fundamentally at odds with each other, and that the particular conflict between êre and varnde guot (line 12) could be resolved if the political circumstances were different. 
Approximately a century later, two linked 'Sprüche' composed by Frauenlob in his 'Grüner Ton' (VII,15-16) clearly reference Walther's Ich saz $\hat{u} f$ einem steine. ${ }^{3}$ At the start of VII, 15, Frauenlob's persona adopts a similarly pensive stance, albeit with some striking differences. Walther's stein has been replaced by a green meadow (uf einer grüne), and, whereas Walther's persona crosses famously crosses his legs (und dahte bein mit beine), Frauenlob deploys a homonym (the preterite form of denken): ${ }^{4}$ Ich saz uf einer grüne / und dachte maniger hande dinc (VII,15,1-2). This punning allusion acknowledges the importance of the 'Reichston' as a pre-text whilst as the same time signalling the intention to proceed in a somewhat different way. It also constitutes the first of a number of word-plays that cumulatively serve to undercut the reliability of

\footnotetext{
${ }^{3}$ The previous 'Spruch' in the Göttingen edition (VII,14) also engages with the topic of ere, albeit in the rather different context of the virtues (e.g. maze; milte; minne) that are desirable for knighthood. There is no particular link to Walther in VII,14, and, beyond the mention of ere, no discursive continuation into VII,15-16. The edition does not present VII,14-16 as a 'Dreierbar'.

${ }^{4}$ For the difference between dâhte (from denken) and dahte (decken), see Hermann Paul, Mittelhochdeutsche Grammatik, 23rd edition revised by Peter Wiehl and Siegfried Grosse (Tübingen: Niemeyer, 1989), §266, p. 260.
} 
language by proving that word and meaning, vox and res, do not necessarily correlate in a straightforward way. ${ }^{5}$

The first question to be addressed by this persona is the challenge of holding on to the benefits of a worldly life without losing God's favour: ${ }^{6}$

wie ich die werlt behielde und ouch gein gote nicht wurde linc. do kunde ich nie erdenken daz, daz mir icht töchte zu socher hande ger. (VII,15, 3-6)

Here, Frauenlob operates with a binary opposition between God and the world that is somewhat different from the ternary of desirable objectives promulgated in the opening 'Spruch' of the 'Reichston'. From the second 'Stollen' onwards, however, Frauenlob's persona concentrates on two of Walther's three desiderata - honour and wealth - whilst the question of God's favour fades somewhat into the background. ${ }^{7}$

\footnotetext{
${ }^{5}$ For this general topic, see Christoph Huber, Wort sint der dinge zeichen. Untersuchungen zum Sprachdenken der mittelhochdeutschen Spruchdichtung bis Frauenlob. MTU 64 (Munich: Artemis, 1977), esp. pp. 127-186 (on Frauenlob). ${ }^{6}$ According to the notes to the Göttingen edition (vol. 2, pp. 881-882), the term link refers to Matthew 25. 33. At the second coming, the sheep will be directed to the right of Christ, and the goats to the left.

${ }^{7}$ According to Joerg Schaefer, Walther von der Vogelweide und Frauenlob. Beispiele klassischer und manieristischer Lyrik im Mittelalter. Hermaea 18 (Tübingen: Niemeyer, 1966), p. 222: 'Frauenlob verengt die Frage nach Gott und der Welt, die er, das Vorbild nachahmend, zu behandeln versprochen hatte, auf das eigentliche innerweltliche
} 
Having described his paradoxical response to the process of reflection, during which he simultaneously loses heart and becomes enboldened, the persona finally achieves one specific insight, namely that nobody ever attains honour without wealth:

Ich wart blöde unde küne von gedanken, der ich vil verschriet, und nach der werlde $t u$ cke min kintheit mir die witze riet, daz nieman in der eren saz

komt ane schaz. des wart min leben swer. (VII,15,7-12)

Verhältnis zwischen Gütern und Ehre, dem ,utile“ und dem „honestum“. . . So verweilt das Denken, das über das gewaltigste Problem nachzusinnen anhebt, bei einer interessanten, aber immanenten Teilgebiet.' However, Franziska Wenzel, 'Souveränität in der Sangspruchdichtung. Intertextuelle und intradiskursive Phänomene bei Walther und Frauenlob', in Sangspruchdichtung um 1300. Akten der Tagung in Basel vom 7. bis 9. November 2013. Spolia Berolinensia 33, ed. by Gert Hübner and Dorothea Klein (Hildesheim: Weidmann, 2015), pp. 167-194, here p. 179, takes the opposite view: 'Doch die im Gattungshorizont aufgerufene Erwartungshaltung wird sogleich unterlaufen, denn dem Ich im Grünen Ton ist es nicht um die Zusammenführung innerweltlicher Werte zu tun. Er sucht vielmehr seinen Platz zwischen Immanenz und Transzendenz zu bestimmen, ohne sich Gott gegenüber link zu verhalten, ohne vom Rechten abzuweichen. Das auf weltliches Ansehen und göttliche Gnade gerichtete Doppelbegehren zeigt das Ich in einen aporetischen Reflextionszustand, denn es gibt nichts, was ihm in dieser Sache weiterhelfen könnte.' 
Here, the self-stylisation of the speaker as youthful or even immature contrasts with the more confident stance of Walther's persona in the 'Reichston'.

Furthermore, the 'Abgesang' of VII,15 moves in an entirely new direction, with the persona engaged in a spat with honour, now fully personified as vrou Ere. Although the motif of a persona arguing with a personification is familiar from the narrative works of the 'Blütezeit' (e.g. by Hartmann von Aue, Wolfram von Eschenbach and Albrecht), ${ }^{8}$ this development further undermines the authority of Frauenlob's persona and sits uneasily within the genre of 'Sangspruchdichtung' that is centrally preoccupied with the construction of a magisterial voice. ${ }^{9}$ At the same time, the scenario whereby a persona engages with one or more allegorical entities in a locus amoenus (in this case, uf einer

\footnotetext{
${ }^{8}$ Cf. Wolfgang Dittmann, “"Dune hâst nicht wâr, Hartmann!” Zum Begriff der wârheit in Hartmanns "Iwein"', in Festgabe für Ulrich Pretzel zum 65. Geburtstag, ed. by Werner Simon (Berlin: Erich Schmidt, 1963), pp. 150-161; Dagmar Hirschberg, 'Zum Aventiure-Gespräch von der Bedeutung warer minne im “Jüngeren Titurel”, in Wolfram-Studien 8 (1984), 107-119, here 108; Annette Volfing, Medieval Literacy and Textuality in Middle High German. Reading and Writing in Albrecht's Jüngerer Titurel (New York: Palgrave Macmillan, 2007), pp. 75-96.

${ }^{9}$ On the typical 'Rollen-Repertoire' in 'Sangspruchdichtung', see Claudia Lauer, Ästhetik der Identität. Sänger-Rollen in der Sangspruchdichtung des 13. Jahrhunderts. Studien zur historischen Poetik 2 (Heidelberg: Winter, 2008), esp. pp. 299-303. Cf. also Claudia Lauer, 'Sangspruchdichtung', in Handbuch Frauenlob, ed. by Claudia Lauer and Uta Störmer-Caysa (Heidelberg: Winter, 2018), pp. 47-75, here p. 56.
} 
grüne) also evokes the genre of the 'Minnerede' ${ }^{10}$ - even if the personification

encountered in VII,15 is by no means the moral authority figure that one might have expected.

The argument opens with the persona accusing vrou Ere of being venal, i.e. too easily influenced by wealth:

Ich strafte vrouwen Eren und sprach, ,ir sit ein swache meit, lat ir iuch schaz verkeren.' (VII,15,13-15)

Given the gendering of the personification, it may also be possible to read this as a more offensive charge, implying the vrou Ere prostitutes herself to anybody who is able to pay. $^{11}$

She retaliates by branding the persona as foolish, but concedes, with a mixture of shame and regret, that he is essentially right - when faced with wealth, she finds herself overwhelmed and unable to assert her inherent preference for virtue:

sie sufte und sprach: ,du tummer, schaz hat mich leider überwegen, man mac min wol mit schatze phlegen, [] schaz ane tugent ist gein mir ein kummer'. (VII,15,16-19)

${ }^{10}$ Cf. Jacob Klinger and Ludger Lieb (eds.), Handbuch Minnereden, 2 vols. (Berlin and Boston: De Gruyter, 2013), vol. 2, pp. 3-4.

${ }^{11}$ Wenzel, 'Souveränität', p. 181, entirely ignores this sexual slur, translating line 14 as 'Ihr seid schwach'. Gert Hübner, 'Hofhochschuldozenten', in Sangspruchdichtung um 1300, pp. 69-87, here p. 79, opts for a more ambiguous formulation: 'Ihr seid ein ordinäres Mädchen’. 
This conception of vrou Ere as a meretrix is striking and stands out within the Frauenlob corpus. Admittedly, Frauenlob often uses the term rather blandly; ${ }^{12}$ according to Karl Stackmann, 'Das Wort bezeichnet an den meisten Stellen ,Ansehen' in recht allgemeiner Weise' ${ }^{13}$ However, in some cases, ere takes on the status of a super-virtue, on a par with Latin caritas or with Wolfram's concept of triuwe: ${ }^{14}$ for example, got ist ere, und ere ist got. (V,61,7), or Die ere ist aller tugent urspring $(\mathrm{V}, 61,13)$. The two 'Sprüche' under discussion go to the other extreme in their construction of ere as something worldly and contingent - much closer to Gottfried's êre âne êre than to Wolfram's triuwe. ${ }^{15}$

After the confrontational dialogue that closes VII,15, the link to Walther is reaffirmed in the next 'Spruch' (VII,16), when Frauenlob returns to Walther's image of the schrîn containing one or more desirable abstract entities. As Franziska Wenzel puts it, 'Im intertextuellen Bezugsfeld des Reichston eröffnet das Herz als Schrein einen

${ }^{12}$ Cf. the entry 'ÊRE' in Karl Stackmann (ed.), Wörterbuch zur Göttinger FrauenlobAusgabe. Abhandlungen der Akademie der Wissenschaften in Göttingen, in cooperation with Jens Haustein (Göttingen: Vandenhoeck \& Ruprecht 1990), pp. 87-88.

${ }^{13}$ Stackmann, Wörterbuch, p. 87.

${ }^{14}$ On Wolfram's use of triuwe, see Jan-Dirk Müller, 'Was heißt eigentlich triuwe in Wolframs von Eschenbach ,Parzival‘?', in Das Mittelalter 20.2 (2015), 311-326.

Retrieved 4 Jul. 2019, from doi:10.1515/mial-2015-0020.

${ }^{15}$ For Gottfried's notion of êre âne êre, see Kathleen J. Meyer, 'The Ambiguity of Honor in Gottfried's Tristan: Lines 17694-17769', in Neophilologus 70.3 (1986), 406-415. 
ethischen Diskursraum. ${ }^{16}$ Nonetheless, the image of the schrîn is deployed very differently by the two poets. For Walther, the schrîn serves primarily as a metaphor that enables him to visualize the ideal of simultaneously possessing guot, weltlich êre and gotes hulde. For Frauenlob, the schrîn, for all its metaphorical potential, is also a material object that constitutes the central prop of the elliptical narrative that makes up VII,16.

This story, the details of which will be discussed further in section III below, concerns the dealings of a rich man with two personifications, vrou Ere and Gelücke. Having attracted the favourable attention of vrou Ere, the rich man locks her in a wellsecured box and entrusts the key to Gelücke. The decision by the latter personification to open the box leads to an unspecified adverse outcome. In the 'Abgesang', Gelücke laments the rich man's failure to take responsibility for his own honour - and acknowledges her own unsuitability for any position of trust: ${ }^{17}$

[,] wan were ich stete, son hiez ich nicht Gelücke. von unsteter phlicht heize ich also, die wort sint nicht gespalden.

The intertextual relationship between Frauenlob's two 'Sprüche' and the opening 'Spruch’ of Walther's 'Reichston’ has received relatively limited critical attention. Jörg Schaefer, writing in 1966, describes VII,15 as an 'Imitation' of Walther, albeit not a

\footnotetext{
${ }^{16}$ Wenzel, 'Souveränität', p. 186.
}

${ }^{17}$ Notwithstanding the fact that the noun gelücke is grammatically neuter, I treat Frauenlob's personification as female, by analogy with Fortuna. For further discussion, section II below. 
particularly successful one (and VII,16 is entirely ignored). ${ }^{18}$ Having commented enthusiastically on Walther's 'energische Position', ${ }^{19}$ he denigrates VII,15 as flabby, ascribing to Frauenlob an intrinsic 'Müdigkeit' which somehow reflects the 'Resignation einer späteren Zeit'. ${ }^{20}$ Whilst more recent critics display greater sympathy for the aesthetic norms governing post-'Blütezeit' literature, their fundamental stance is not so very different. Gert Hübner, for example, raises the possibility that with VII,15, Frauenlob might have intended 'eine Überbietung des Vorbilds durch eine komplexere inventio oder elocutio', ${ }^{21}$ but concludes that the achievement falls far short of this:

Der erste Stollen scheint mir nämlich Walthers ernste Denkerpose so zu banalisieren, dass die parodierende Formulierung - der Sangspruchdichter sitzt auf der Wiese und denkt allerhand - auch die bedachte Frage als eine eher simple ausweist, die bei Lichte besehen weder intellektuelles Verzagen noch geistige Kühnheit rechtfertigen kann [. . .] Das dumme Sangspruchdichterkind erteilt der Ehre selbst das Wort, um der nicht eben komplexer Reflexion bedürftigen Wahrheit über das Verhältnis zwischen Ehre und Reichtum Lehrautorität zuzuweisen. $^{22}$

${ }^{18}$ Schaefer, Walther, p. 220.

${ }^{19}$ Schaefer, Walther, p. 221.

${ }^{20}$ Schaefer, Walther, p. 223.

${ }^{21}$ Hübner, 'Hofhochschuldozenten', p. 79.

${ }^{22}$ Hübner, 'Hofhochschuldozenten', p. 79. 
In the same volume, Franziska Wenzel devotes a substantial article to examining the ways in which Frauenlob uses both VII,15 and VII,16 to position himself in relation to Walther. ${ }^{23}$ Nonetheless, she too looks for clear-cut didactic content in these 'Sprüche':

Die Beständigkeit, das ist die implizite Konsequenz, ist die Spezification der geforderten Vollkommenheit des Menschen, durch die der Reichtum und das Ansehen eine maßvolle Verbindung einzugehen vermögen; ${ }^{24}$

and, despite having previously commented on the 'aporetischen Reflextionszustand' of the hesitant persona ${ }^{25}$ she takes at face value the claim that die wort sint nicht gespalden:

${ }^{23}$ Wenzel, 'Souveränität'. However, her decision to base her interpretation on the order of strophes in the Jenaer Liedhandschrift $(\mathrm{J})$ rather than in the Göttingen edition has the effect of weakening the link, not only between VII,15 and VII,16, but also between Frauenlob and Walther. In J, the 'Spruch' that in the Göttingen edition is presented as VII,11 (=J 71) appears between the two 'Sprüche' that form the subject of this article (VII,15=J 70; VII, 16=J 72). VII,11 is a cosmological 'Spruch' presenting the created universe as a diamond $v a z$ (not a schrîn), with the earth as a piece of iron skillfully placed at the very centre. Although Wenzel derives significance from the contrast between the cosmological 'Spruch' and the two others (i.e. the certainty of the divine order as opposed to the contingencies and imperfections of human life), this approach does not do justice to the way in which VII,15 and VII,16 constitute a sustained and varied engagement with some of the key terms of Walther's 'Spruch' (reflection; honour and wealth; and the containment of abstract entities in a box).

${ }^{24}$ Wenzel, ‘Souveränität', p. 186.

${ }^{25}$ Wenzel, ‘Souveränität', p. 179 (see footnote 7 above). 
In dessen [=Gelückes] Postulat, dass sich ein jeder Mensch selbst und beständig um sein Ansehen bemühen muss, ist der Sinn nicht mehr gespalten. Die Aussage ist in ihrer Bedeutung klar. ${ }^{26}$

The present discussion will seek to repudiate these charges of banality and of simplistic didacticism on the part of Frauenlob.

\section{II}

Frauenlob's entire corpus is marked by an interest in personification allegory and in the heirarchical order of abstract entities. As Christoph Huber has shown, he is amongst the most prominent Middle High German writers to draw on the literary and intellectual tradition of Alan of Lille, with both the Minneleich and Minne und Welt probing the powers and the limitations of Natura within the divine order. ${ }^{27}$ Although the personification of Fortuna is not associated as strongly with the Anticlaudianus of Alan of Lille as is that of Natura, Alan does present the former personification in a way that is entirely consistent with Frauenlob's approach. The initial observations on the constant inconstancy of Fortuna are entirely conventional, for example:

\footnotetext{
${ }^{26}$ Wenzel, ‘Souveränität', p. 187.

${ }^{27}$ Christoph Huber, Die Aufnahme und Verarbeitung des Alanus ab Insulis in mittelhochdeutschen Dichtungen: Untersuchungen zu Thomasin von Zerklaere, Gottfried von Straßburg, Frauenlob, Heinrich von Neustadt, Heinrich von St. Gallen, Heinrich von Mügeln und Johannes von Tepl. MTU 89 (Munich: Artemis, 1988), pp. 136-199. Cf. also Martin Bartel, 'Sin lib, sin gut mir blibet. Frauenlob, Frau Welt und seine AlanusRezeption im Sangspruch VII,30', in ZfdA 143 (2014), 166-182.
} 
hoc solo verax quod semper falsa probetur,

hoc solo stabilis quod semper mobilis erret. (VIII,28-30) ${ }^{28}$

[[She is .. ] truthful only in that she is always found to be false; stable only in being always unstable.]

However, the scene in which Alan's Fortuna is invited to bestow her gifts on the homo novus takes the paradox a step further, as the personification admits to her own trickery and expresses a wish to improve, at least temporarily:

Sed tamen hic nostros conabor vincere lapsus et vires inferre mihi; mutabo propinquas fraudes atque mei deponam taedia casus. Me reddam stabilem, motum pro parte recidens; incipiam sollers sapiens discretaque verax et stabilis fieri, quae stulta improvida mendax et praeceps hucusque fui; mutabo priores excessus, nostrasque manus mirabor ad horam.

(VIII,98-105)

[Yet in this case I will try to overcome my failing and turn my powers against myself. I will change my native deceitfulness and lay aside my tiresome randomness. I will make myself stable, ceasing my movement for a while. I will begin to become serious, wise, judicious, truthful, and stable, I who have hitherto been foolish, careless, false and impulsive. I will change my old aberrant ways and for a time marvel at my handiwork.]

The irony of this passage is that in seeking to vary her behaviour by turning virtuous, Fortuna is only compounding her own fickleness and changeability. As will be discussed in Section III below, a similar irony attaches to the discourse of the apparently plainspeaking Gelücke in Frauenlob's VII,16. The way in which Alan's Fortuna suddenly seeks to remodel herself also matches the approach taken in some of Frauenlob's 'Sprüche' in

${ }^{28}$ Alan of Lille, Literary Works, ed. and translated by Winthrop Wetherbee (Cambridge, Mass.: Harvard University Press, 2013). 
the 'Langer Ton'. As will be shown below, these 'Sprüche' interweave conventional statements about the fickleness of fortune with sudden assertions to the opposite effect namely that good fortune comes precisely to those who deserve it.

The relationship between gelücke and Fortuna in Middle High German writing is long-standing and multi-faceted. Willy Sanders argues that in earlier contexts, the two can be distinguished insofar as Fortuna functions as a female personification deploying her agency in turning her wheel, whereas gelücke typically signifies either the wheel itself, or the kind of experience produced by the turning of the wheel. ${ }^{29}$ Later, however, Gelücke becomes more closely aligned with Fortuna herself and is arguably to be visualized as a female figure. In Frauenlob's writing, both of these approaches are represented, and are typically distinguished in the Göttingen edition through capitalization: gelücke tends be the experience (either good or bad) which is meted out to human beings, whilst Gelücke is construed as a personified entity, complete with physical agency, a speaking voice, and various iconographic attributes. These attributes include the wheel, but also some some less traditional items, as will be discussed below. The Boethian distinction between Fortuna and Providence does not have any bearing on Frauenlob's presentation of gelücke. ${ }^{30}$ Frauenlob's gelücke also stands in a somewhat

${ }^{29}$ Willy Sanders, Glück. Zur Herkunft und Bedeutungsentwicklung eines mittelalterlichen Schicksalsbegriffs. Niederdeutsche Studien 13 (Cologne: Böhlau, 1965), p. 26.

${ }^{30}$ Cf. Peter Ganz, 'Fortuna bei Frauenlob', in Fortuna. Fortuna Vitrea 15, ed. by Walter Haug and Burghart Wachinger (Tübingen: De Gruyter, 1995), pp. 76-87, here p. 87. 
complex relationship to selde. ${ }^{31}$ Although these two terms are sometimes used synonymously, selde may also have a more prominent ethical or even ethical component. Frauenlob's 'Spruch' V,53, for example, presents selde in opposition to gelücke - as will be discussed below.

Whilst the term gelücke occurs less frequently than ere in Frauenlob's overall corpus, it is accorded central importance in the 'Langer Ton' ${ }^{32}$ Here, the texts in question are the individual 'Sprüche' V,62, V,88 and V,89 and the 'Dreierbar' V,51-53. ${ }^{33}$ The three individual 'Sprüche' provide divergent perspectives on the concept. V,62 talks in very general terms about the vicissitudes of war, suggesting that gelücke wove the garments for urliuge. ${ }^{34} \mathrm{~V}, 88$ and $\mathrm{V}, 89$ both encourage the audience to consider the extent

31 Cf. the entry 'SÆLDE' in Stackmann, Wörterbuch, p. 300.

${ }^{32}$ For a detailed study of Frauenlob's 'Langer Ton', especially in the context of manuscript transmission, see Franziska Wenzel, Meisterschaft im Prozess. Der Lange Ton Frauenlobs - Texte und Studien. Mit einem Beitrag zu vormoderner Textualität und Autorschaft, Deutsche Literatur. Studien und Quellen 10 (Berlin: De Gruyter, 2012); also Franziska Wenzel, 'Meisterschaft und Transgression. Studie zur Spruchdichtung am Beispiel des Langen Tons der Frauenlob-Überlieferung', in Das fremde Schöne.

Dimensionen des Ästhetischen in der Literatur des Mittelalters, ed. by Manuel Braun and Christopher Young (Berlin: De Gruyter, 2007), pp. 309-334.

33 These 'Sprüche' are all discussed in some detail by Ganz, 'Fortuna'.

${ }^{34}$ See also Wenzel, Meisterschaft im Prozess, p. 198. 
to which they deserve good fortune. ${ }^{35} \mathrm{~V}, 88$ does so by proposing an unusual correlation between virtue and gelücke, according to which good fortune will not be able to evade those with a record of good deeds. ${ }^{36} \mathrm{~V}, 89$, by contrast, presents Gelücke as holding a mirror. People are encouraged to look into this mirror and consider how to improve themselves. However, they are also warned that the opportunity for reflection may be short-lived and the mirror may be whisked away at any point. As Gelücke is also credited with a tendency to blind people and to present distorting images (V,89,12: gougelblic), one may safely say that this personification lacks any commitment to furthering genuine self-scrutiny.

The 'Dreierbar' V,51-53 also stresses the changeable nature of Gelücke, approaching the topic in ways that provide a helpful foil for interpreting VII, $15-16 .{ }^{37}$ Much like VII,15, which focuses on the persona's attempt to challenge vrou Ere, V,51 uses a question from the persona as a way of allowing the personification Gelücke to affirm her essential characteristics. Gelücke flaunts her own inconstancy and describes the various iconographic attributes that illustrate this: she possesses not only the familiar wheel, but also a bühse full of gougelschicht (cf. V,89,12: gougelblic) and a drinking

${ }^{35}$ See also Wenzel, Meisterschaft im Prozess, pp. 218-219.

${ }^{36} \mathrm{~V}, 88,13-16:$ Und swaz du gutes hast getan, / und kom nicht von derselben ban: / gelücke kan

I dir nicht engan. Ganz, 'Fortuna', p. 85 translates this as follows: 'Was Du auch Gutes getan hast, weiche nicht von diesem Wege ab. Dann kann dir das Glück nicht entgehen.'

${ }^{37}$ On this 'Dreierbar', see also Wenzel, Meisterschaft im Prozess, pp. 213-215. 
vessel that intoxicates. Deception and unreliability are central themes - but at the same time, Gelücke, like Alan's Fortuna, is entirely upfront about her own practices. V,52, the next 'Spruch' in the 'Dreierbar', adopts a similar stance to that of V,88 insofar as gelücke is no longer personified, or even associated with randomness and inconstancy. On the contrary, good and bad destinies are apparently handed out on the basis of merit. Finally, $\mathrm{V}, 53$ is of particular interest for the interpretation of VII,16 because it discusses the relationship between gelücke, selde and ere. V,53 presents numerous interpretational challenges, but Peter Ganz argues that it essentially construes selde as superior to gelücke: whilst the latter can only bring temporary enjoyment and sensual pleasure (lieb unde lust), selde (selikeit) can deliver lieb in a more permanent and virtuous combination with wol. ${ }^{38}$ This second pair of gifts (lieb unde wol) is then clothed in ere, here imagined as a textile rather than as a person:

Lieb unde lust gelücke treit, lieb unde wol ist selikeit. der zweier cleit schöne und gemeit, daz heizet ere sunder leit, [] ob sie sint ane gunterfeit. (V,53,13-18)

${ }^{38}$ Ganz, 'Fortuna', pp. 81-82. On the pair liep and lust, see Thomas Bein, Sus hup sich ganzer liebe vrevel. Studien zu Frauenlobs Minneleich. Europäische Hochschulschriften 1062 (Frankfurt am Main: Peter Lang, 1988), pp. 264-267; Thomas Bein, 'Liep unde lust. Beobachtungen zu einem ,Minneprinzip“ Frauenlobs unter besonderer Berücksichtigung von VII 38-40', in Wolfram-Studien 10 (1988), 159-168; Christoph Huber, 'Frauenlob zum Minneprozeß', in Wolfram-Studien 10 (1988), 151-158. 
Similarly, anybody who enjoys the favour both of God and of the world should ascribe this privilege to the operations of selde rather than of gelücke:

Swem wol geschicht gein got und gein der werlte wesen, diz wol genesen, daz heizet selde kreftig, mislich, sigeheftig.

For the purposes of understanding VII,16, the most striking aspect of V,53 is the implicit dissociation of ere from gelücke and from everything which the latter has to offer: real ere is associated exclusively with the gifts of selde. This normative framework contrasts with the highly scenario in VII,16, in which vrou Ere is shown to be entirely in the power of Gelücke.

\section{III}

In 'Spruch' VII,16, Frauenlob builds upon the confrontation between vrou Ere and the persona of VII, 15 by carrying the personification forward into a short, elliptical exemplum. The opening 'Stollen' describes - in uncharacteristically plain language - how vrou Ere approaches a rich man and expresses the wish to remain with him:

Vrou Ere quam gegangen

$\mathrm{zu}$ einem gutes richen man.

er vragte, wer sie were. ,ich binz, vrou Ere,' sprach si san, ,und wolde gerne bi dir sin.' ,des bin ich vro,' sus sprach des schatzes zogel. (VII,16,1-6)

If one reads this 'Spruch' without any reference to the previous dialogue between vrou Ere and the persona, it would possible to assume that this particular man happens to 
be both rich and virtuous - in other words, that vrou Ere has singled him out because he is truly worthy of her company. However, given what has just been said by both parties about the venality of vrou Ere, it seems more likely that she has selected this individual solely on account of his wealth. The fact that he does not immediately recognize her supports this reading, as does the specification in line 2 that he is gutes rich-i.e. not rich in any other respect. Furthermore, the phrase des schatzes zogel is significant in that it describes the man in terms of his ability to pull or draw wealth to himself. ${ }^{39}$ This same ability has also enabled him, however unwittingly, to attract vrou Ere. It is also worth noticing the slight shift in the presentation of vrou Ere: in the VII,15, she presented herself as too weak to prevent herself from being overpowered by wealth, whilst here, she seems to take a more active role in soliciting rich men.

The second 'Stollen' reports the sudden confinement of vrou Ere inside an ornate and well-secured box: Ein schrin, der was mit spangen / beslagen, da in er sie besloz. (VII,16,7-8). Without the connection, via the previous 'Spruch', to Walther's notion of confining three desiderata in one box, this might seem like an odd move on the part of the rich man. Given that a negative outcome results from the decision to lock away something precious, it is potentially tempting also to link this exemplum to the parable of the talents (Matthew 25. 14-30; Luke 19. 11-27), in which a nervous servant is castigated for having buried the resources allocated to him, rather than using them freely and

\footnotetext{
${ }^{39}$ Cf. the entry 'ZOGEL', in Stackmann, Wörterbuch, p. 499: 'Jmd., der zieht: sus sprach des schatzes zogel (gemeint wohl: der, welcher einen Schatz an sich gezogen hat, der Reiche) VII,16,6.'
} 
productively. However, the rest of VII,16 does not encourage this line of thought. As it turns out, the rich man is not blamed for having imprisoned vrou Ere in the first place, but rather for not having kept the box secure by holding on to the key himself. Within the framework set up by Walther, the schrin equates to the human heart (I.2.I,15; I.2.I,19), and it is perfectly legitimate to want to enclose the specified desiderata within it.

A major difference between VII,16 and Walther's 'Spruch' is the fact that Frauelob presents honour, not just as a three-dimensional object, but as a full-scale, gendered personification. However, whilst it might seem transgressive and cruel to imprison a visiting lady, the rich man's action is understandable - and even commendable - in the context of the literary motif of a female figure willingly enclosed within the implausibly narrow confines of the human heart (e.g. Orgeluse in the heart of Gawan, or vrou Aventiure in the heart of Wolfram's narrator). ${ }^{40}$ This hint of a 'Minne'-association also adds to the eroticization of vrou Ere already suggested in the previous strophe.

\footnotetext{
${ }^{40}$ On this literary motif, see Nigel Palmer, 'Herzeliebe, weltlich und geistlich. Zur Metaphorik vom “Einwohnen im Herzen” bei Wolfram von Eschenbach, Juliana von Cornillon, Hugo von Langenstein und Gertrud von Helfta', in Innenräume in der Literatur des deutschen Mittelalter. XIX. Anglo-German Colloquium Oxford 2005, ed. by Burkhard Hasebrink et al. (Tübingen: Niemeyer, 2008), 197-224. Cf. Wolfram von Eschenbach, Parzival. Bibliothek des Mittelalters 8.1-2, ed. and commentary by Eberhard Nellmann based on the edn. by Karl Lachmann, transl. by Dieter Kühn, 2 vols. (Frankfurt am Main: Deutscher Klassiker Verlag, 1994), 584,5-29 (Orgeluse); 433,1-434,10 (vrou Aventiure).
} 
The remainder of the second Stollen describes how the rich man's relationship with vrou Ere is complicated by the involvement of a different personification, Gelücke. Rather than cherishing the new occupant of his box/heart, he passes the key on to Gelücke:

dem Gelücke er gab den slüzzel und sprach: ,sich hin, phlic dins genoz. Gelücke quam eins zu dem schrin und sloz in uf, do was ez ein gouchesvogel. (VII,16,9-12)

Frauenlob's use of plain language is not sustained for long: these lines present several interpretational challenges, notable in relation to the instruction phlic dins genoz and to the image of the gouchesvogel.

It is unclear which figure is to be understood as the genoz of Gelücke. The term could possibly refer to the rich man, who might view himself, somewhat naively, as the companion or ally of Gelücke. On that basis, he might feel justified in asking Gelücke to help or support him by safeguarding his interests. Alternatively, and more plausibly, the term genoz may refer to vrou Ere; i.e. she is being presented as the 'fellow' personification of Gelücke. This reading raises further questions: is Gelücke is being entrusted with safeguarding her 'fellow' personification from the outside (i.e. she is like an external jailer who holds the key), or is she being asked to get into the box to join her companion vrou Ere? This last possibility would tie in with Walther's idea of the desirability of keeping several abstract entities in a single box - although admittedly there is something illogical about having two personifications living in the same place, with one of them being effectively imprisoned and the other free to come and go. 
The term gouchesvogel is used to sum up the disaster that results from the unlocking of the box by Gelücke. Whether or not this action is done on the instruction of the rich man or in contravention of his orders depends on how one assesses the various options just outlined. It would seem that Gelücke, like Pandora, has opened a box that should have been left locked. In this case, however, the problem is not that bad things are released, but rather that something good (vrou Ere) departs from the box - and possibly also that something less good enters it. The term gouchesvogel evokes the idea of a cuckoo being placed in a nest where it does not belong, and from which it displaces the proper inhabitants. But who or what plays the role of the cuckoo in this allegorical scenario?

To the extent that the schrin is to be understood, not as a prison, but rather as a kind of nest or sanctuary for vrou Ere, it would seem that she is indeed displaced as a result of the actions of Gelücke. Assuming that Gelücke goes right into the box (on the instruction of the rich man), it makes sense to regard her as the gouchesvogel: she enters and thereby pushes out vrou Ere, who, for all her shortcomings, was still a worthier resident. On the other hand, one might think of Gelücke as an inadequate jailer who stays outside the box, but opens it without good reason. On this account, Gelücke might be guilty of letting in a gouchesvogel - i.e. an alien or undesirable element - into a space that ought to be reserved purely for vrou Ere. However, the text does not provide any further information as to the identity of the intruder who displaces vrou Ere. Finally, is also possible to combine the notion of Gelücke as the inadequate jailer with the idea of Gelücke herself is the gouchesvogel. This would involve focussing on the relationship between Gelücke and the rich man, rather than on the relationship between 
Gelücke and vrou Ere. Just as the cuckoo usurps the proper, legitimate nestling, so Gelücke is usurping the role of the rich man who (in this context) has proper ownership of vrou Ere.

In the 'Abgesang', Gelücke is given a voice - just as the 'Abgesang' of the previous 'Spruch' provided vrou Ere with a speaking role. There are further parallels, including that repetition of und sprach (cf. VII,15,14), and of the adjective tumm (cf. VII,15,16) that is applied by each personification to her human interlocutor:

Do clagete Gelücke sere und sprach: ,er ist ein tummer gouch, swer mir bevilht sin ere... '

(VII,16,13-15)

It is not entirely clear why Gelücke should lament - is this figure seriously distressed at the departure of vrou Ere, or is she responding to implicit criticism from the rich man? Gelücke certainly sounds defensive. The shift in meaning in the term gouch is also striking: this term now no longer means 'cuckoo'/'usurper'/‘bastard', but now simply 'fool'. ${ }^{41}$ The repetition of the term, but with a new meaning, seems entirely consistent with the idea that the rich man has chided Gelücke for being the gouchesvogel who displaced vrou Ere. Having been reprimanded in this way, Gelücke may reasonably retort: 'Who are you calling a gouch(esvogel)? You yourself are ein tummer gouch.' We

\footnotetext{
${ }^{41}$ Both meanings are common in Middle High German. See the entry 'gouch' in Matthias Lexer, Mittelhochdeutsches Handwörterbuch, 3 vols. (Leipzig: Hirzel, 1872-1878), vol. 1, pp. 1057-1058. Frauenlob possibly references both meanings in VIII,24,19-21: waz sol dem sanc / und seiten clanc, / der lieber hort den gouch? Cf. the entry 'GOUCH' in Stackmann, Wörterbuch, p. 130.
} 
note also the shift from vrou Ere as an individual figure representing the quasi-Platonic Idea of honour, and the phrase sin ere which just refers to the renown of a particular individual. In introducing both of these shifts in meaning, Gelücke is demonstrating her own linguistic dexterity - and the slippery nature of language.

Gelücke goes on to explain that a man should take responsibility for his own honour, rather than delegating that task to somebody else, and least of all to Gelücke herself:

[,] er solte ir selber walden. wan were ich stete, son hiez ich nicht Gelücke, von unsteter phlicht heize ich also, die wort sint nicht gespalden. ' (VII,16,13-15)

Taken in isolation, this pair of recommendations - to look after one's own honour and not to trust fortune - are entirely conventional. It would also be possible to use these recommendations as the basis for a rather simple moralisatio that would fit the exemplum as a whole: 'If you think you can hold on to honour simply by virtue of your wealth, you are mistaken, because fortune is quite capable of taking away your wealth, and, with it, your honour.' This is similar to the reading of these lines that is proposed by Wenzel (see section I above). ${ }^{42}$

However, to regard any moralisatio of this kind as the point or message of VII,16 would sit uneasily with the way in which the story is actually told. In this 'Spruch', there is no explicit reference to the rich man believing that that his wealth entitles him to honour, nor even a reference to his losing his wealth. We do not know exactly why or

\footnotetext{
${ }^{42}$ Wenzel, ‘Souveränität', p. 187.
} 
how vrou Ere disappears, only that Gelïcke opens the box and that this is a bad thing.

The man supposedly makes a mistake when he associates vrou Ere and Gelücke too closely with each other, and yet these two entities seem to be intimately connected by the very nature of things. After all, both of these two linked 'Sprüche' operate with a vrou Ere who follows the money, and money is ultimately in the gift of Gelücke. ${ }^{43}$

The difficulties of interpreting V,16 are extreme, even by medieval standards. For readers of maren, and of other didactic or exemplary texts, the challenge of reconciling narratio and moralisatio is well-known. ${ }^{44}$ In most cases, however, each of these two

${ }^{43}$ The association of Fortuna with money is a medieval topos. See for example Tuomas M. S. Lehtonen, Fortuna, Money and the Sublunar World. Twelfth-century Ethical Poetics and the Satirical Poetry of the Carmina Burana. Bibliotheca Historica 9 (Helsinki: Gummerus, 1995), esp. pp. 125-128.

- ${ }^{44}$ Walter Haug, 'Entwurf zu einer Theorie der mittelalterlichen Kurzerzählungen’, in Kleinere Erzählformen des 15. und 16. Jahrhunderts. Fortuna Vitrea 8, ed. by Walter Haug and Burghart Wachinger (Tübingen: Niemeyer, 1993), pp. 1-36, promotes the view 'daß es bei der Kurzerzählung um die Darstellung des Sinnlosen gehe' (p. 8), notwithstanding the prominence of promythia and epimythia within this genre. On the difficulty of reconciling actual story-lines with the interpretative directives provided, see Björn Reich and Christoph Schanze (eds.), Narratio und Moralisatio. BmE Themenheft 1 (Oldenburg: BIS-Verlag der Carl von Ossietzky Universität Oldenburg, 2018); and especially the article in that volume by Friedrich Michael Dimpel, 'Axiologische Dissonanzen. Widersprüchliche Aspekte der evaluativen Struktur in „Der Feige 
rhetorical components will be reasonably coherent in itself. Even if the connection between the two is unconvincing by modern standards, we will generally know what has happened in a story, and we understand what we are (ostensibly) being directed to think about it. In VII,16, however, the story-line, for all its slightness, is riddled with gaps and inconsistencies, so that events and motivations have to be supplied by reading between the lines. At the same time, the moralisatio, such as it is, not only fails to tie in with the story-line, but also loses credibility through being formulated by a figure who openly states that she cannot be trusted.

The proclamation made by Gelücke of her own unreliability may just be read as an affirmation of the status quo: given that it is in the nature of fortune to be inconstant, it was foolish of the rich man to expect anything else. However, this essentialist view of the world is also underpinned by etymological argument: by claiming to have derived her

Ehemann“ und „Die drei Mönche zu Kolmar“", pp. 123-156. For narratives within the genre of 'Sangspruchdichtung', see also Franziska Wenzel, 'Textkohärenz und Erzählprinzip. Beobachtungen zu narrativen Sangsprüchen an einem Beispiel aus dem „Wartburgkrieg“-Komplex’, in ZfdPh 124 (2005), 321-340, in which she discusses the various forms of incomplete narration (p. 335: 'unterbrochenes bzw. abgebrochenes Erzählen, assoziatives Erzählen, konnotatives Erzählen, aggregatives Erzählen durch thematischen Wechsel usf.'). 
name von unsteter phlicht, ${ }^{45}$ Gelücke draws on the popular, though spurious, etymology of ge-lücke, based on the adjective lücke (meaning 'lying, deceiful'). ${ }^{46}$

The final claim (die wort sint nicht gespalden) is as puzzling as the rest of this 'Spruch'. On one level, this seems to be an assertion to the effect that gelücke and unstete mean the same thing. If these particular words cannot be separated or distinguished from each other, people should not be surprised at changes in fortune. On another level, however, the statement reads as a reassuring but vague affirmation of the integrity of words and language more generally. But what exactly is being affirmed? That words cannot, or should not, be split or broken down into their etymological components? Or that words cannot be severed from their meanings?

Etymological discussion plays a prominent part in the writing of Frauenlob, and his famous deconstruction (in 'Spruch' V,103,16) of the term vrowe into the components vro and we provides one prime example of how a word may legitimately be gespalden. ${ }^{47}$ Furthermore, Gelücke's allusion to the derivation of her own name (ge-lücke) implicitly endorses the principle of etymological deconstruction. Either her closing statement is therefore not, in fact, about etymological deconstruction at all, or it is a lie that demonstrates precisely how truly she spoke when describing herself as unreliable.

\footnotetext{
${ }^{45} \mathrm{Cf}$. the similar formulation in V,51,13-14: Wan hete ich zu der stete pflicht, / so hieze ich ouch gelücke nicht.

${ }^{46}$ Sanders, Glück, p. 231.

${ }^{47}$ On the importance of etymology for Frauenlob, see Huber, Wort, pp. 163-167..
} 
On Frauenlob's overall theory of language, Huber argues that he does not operate with any notion of a God-given one-to-one correspondence between a word and the thing or concept to which it points. ${ }^{48}$ For Frauenlob, words are signs that have been established in a variety of different ways; while some terms have their origins in nature (e.g. verbs based on animal sounds), most are arbitrary in the sense of having acquired their meanings as a result of practice and convention. Nevertheless, once established, this system of signs amounts to an ordo that broadly reflects the world that it is trying to describe: 'Dieser [der Zeichenstatus des Worts] beruht auf freier Setzung, die aber nicht willkürlich und unbegründet sein sollte. ${ }^{49}$ Ultimately, it should therefore be the case that:

Die Realisierung der allgemeinen Ordnung ist mit der Ordnung der Sprache verbunden, die in der konkreten Situation das Rechte 'recht' macht und das Unrechte 'unrecht' nennt. ${ }^{50}$

Nonetheless, there are cases in which definitions no longer hold true, and established terms become meaningless This is typically the result of something having gone wrong in the social and ethical structures which language attempts to reflect: for example, if reht avails itself of violence, san ist sin nam verworden (V,22,6). ${ }^{51}$ Another

\footnotetext{
${ }^{48}$ Huber, Wort, p. 149: 'Nirgends wird eine "Identität” von Wort, Begriff, platonische Idee behauptet.'

${ }^{49}$ Huber, Wort, p. 149. Cf. also p. 138: 'Die Sprachgestalt ist hier Ausdruck der Dingordnung.'

${ }^{50}$ Huber, Wort, p. 188.

${ }^{51}$ Cf. Huber, Wort, 171.
} 
striking example from the 'Langer Ton' sets out the possibility of a word having two conflicting meanings:

Man mag gewinnen gut, daz ez nicht heizet gut.

gut gutlich tut, mit gute gut man tribet. [] gut, det nam beclibet dem schatze nicht, wan ob der schaz ' 'uf daz gut sich' schibet: so zimet im des gutes recht, sit er nach gute ringet. (V,50,1-6)

Here, the two meanings of the term gut ('good' and 'material wealth') are played against each other..$^{52}$ The point is that wealth is a normally deemed to be a good thing, and so the two meanings cohere. However, this ceases to be the case if the wealth is not handled well - resulting in the paradoxical assertion that gut should not be called gut.

Linguistic paradox, ambiguity and equivocation are thus symptomatic of problems within the 'Dingordnung'. Of course, some examples have greater polemical potential than others: it is more controversial to claim that reht has become meaningless, or that the two meanings of gut are irreconcilable, than it is to draw attention to the fact that the preterite forms of decken and denken sound quite similar (VII,15,2). Nonetheless, an accumulation of even such relatively minor linguistic ambiguities has a destabilizing effect and undermines confidence in the system of proper correspondences between signum and res. The two 'Sprüche' responding to Walther not only contrast the two preterite forms, but also the two meanings of gouch. There is also a play on the common root of the imperative form phlic and the abstract noun phlicht: although these terms do not diverge as starkly in meaning, their relatively close juxtaposition foregrounds the way

${ }^{52}$ Cf. Huber, Wort, 171. 
in which language is subject to subtle semantic shifts. Furthermore, the fact that both 'Sprüche' feature a Lady Honour who is somewhat dishonourable provides a striking case of how a name might become verworden.

Finally, the very nature of Gelücke takes the discussion a step further towards outright untruth (described by Huber as 'pervertiertes Sprechen.' ${ }^{53}$ Her sudden display of virtuous candour in admitting to her own untrustworthy nature constitutes a logical conundrum on a par with the paradox 'This is a lie.' ${ }^{54}$ She may be speaking the truth when claiming that die wort sint nicht gespalden (in the sense that this statement is not entirely at odds with Frauenlob's view of how language works under ideal circumstances). However, given her identity as Ge-lücke, a truthful statement about language would mean that her own name has just become verworden - a development that would undercut the validity of what has just been asserted. ${ }^{55}$

${ }^{53}$ Huber, Wort, p. 171.

${ }^{54}$ For an overview of the so-called 'Liar Paradox', see Robert L. Martin, The Paradox of the Liar (New Haven, Conn.: Yale University Press, 1970); ibid., Recent Essays on Truth and the Liar Paradox (Oxford: Oxford University Press, 1984).

${ }^{55}$ Christoph Huber, 'Frauenlob als Theologe und Philosoph', in Handbuch Frauenlob, pp. 109-146, here p. 146, rightly highlights the need for further research into Frauenlob's approach to ethics across the entire corpus. Until a better understanding of this wider area has been achieved, it is difficult to assess the full ramifications of of the apparently radical linguistic scepticism expressed these two 'Sprüche'. 


\section{IV}

The gist of Frauenlob's response to Walther is that things are more complicated than suggested in the Ich saz ûf einem steine. Whilst Walther's 'Reichston' articulates fierce and confident protest, Frauenlob's two 'Sprüche' are marked by verbal and conceptual aporia. The incomplete narration, the puns, the word-games and the paradoxes all suggest that with the intellectual tools available, engagement with existential questions can only be tentative, provisional and indirect. It therefore seems entirely appropriate that the persona in VII,15 should be blöd, the rich man in VII,16 a gouch, and both labelled tumm by their unreliable allegorical interlocutors. It also seems appropriate that Frauenlob should make two attempts to respond to Walther - first by placing his persona in dialogue with a personification, and then by using the more oblique device of an allegorical exemplum. The recourse to two 'takes', each offering a different perspective, effectively acknowledges the limitations of either approach, and the impossibility of a single, exhaustive solution to this existential quandry.

As already noted by Schaefer, Frauenlob rejects the 'politische Aktualität' underpinning the 'Reichston', ${ }^{56}$ in favour of a more introspective and philosophical approach:

Während Walthers Gedicht in den von der Plastik getragenen Gedanken sich ausweitet zu den geschauten Straßen im Großraum des Reichs, bleibt das Ich in Fraunlobs Strophe bei sich und seinem gestaltlos gegebenen denkenden Selbst. ${ }^{57}$

\footnotetext{
${ }^{56}$ Schaefer, Walther, p. 221.

${ }^{57}$ Schaefer, Walther, p. 221.
} 
According to Frauenlob's two 'Sprüche', the relationship between honour and wealth is intrinsically problematic, regardless of any specific external circumstances. Furthermore, the issue is not, as in Walther's 'Spruch', that these two entitites are essentially at odds with each other, in such a way that it is difficult to for a rich man to be honourable, or for an honourable man to be rich - not to mention the additional problem of also retaining gotes hulde. Instead, Frauenlob presents honour as almost parasitical on wealth - and his use of personification as a rhetorical device enables him to present the questionable ethical nature of the concept: this vrou Ere is unduly attracted to wealth (in both 'Sprüche'), and therefore fundamentally dependent on Gelücke, the personified dispenser of wealth (in VII,16). As a result, honour in these 'Sprüche' is both dishonourable and lacking in conceptual autonomy, to such an extent that it hardly qualifies as an independent desideratum.

Whereas Walther's persona worries about how to contain three desiderata in one box, the protagonist of VII,16 fails to retain even one. However, the subordination of vrou Ere to wealth and to Gelücke arguably means that the rich man cannot be blamed for his failure. It is all very well for Gelücke to tell him not to delegate the important task of minding his own honour; however, given the venality of vrou Ere, Gelücke effectively holds the key all along. On this reading, the rich man's mistake is not so much that he entrusts the key to Gelücke - but rather that he is surprised by changing circumstances in a world that is marked by instability and contingency. This means that, although Gelücke does, in one sense, displace vrou Ere by opening the box, in another sense that box never actually contained anything of value. 
(8439 words) 